\title{
Assessing the Antecedents of Customer Loyalty on Healthcare Insurance Products: Service Quality; Perceived Value Embedded Model
}

\author{
Fadi Abdelmuniem Abdelfattah ${ }^{1}$, Muhammad Sabbir Rahman², Mohamad Osman ${ }^{1}$ \\ ${ }^{1}$ Multimedia University, ${ }^{2}$ International Islamic University Malaysia (Malaysia) \\ fadifattah@yahoo.com, sabbiriiu@gmail.com,osman.mohamad@mmu.edu.my
}

Received: May 2015

Accepted: December 2015

\section{Abstract:}

Purpose: This research aim to investigate the influence of service quality attributes towards customers' loyalty on health insurance products. In addition, this research also tested the mediation role of perceived value in between service quality and customers' loyalty on health insurance products.

Design/methodology/approach: Based on the literature review, this research developed a conceptual model of customers loyalty embedded with service quality and perceived value. This research applied convenience sampling method. The study surveyed 342 healthcare insurance customers through self-administered questioner. Apart from assessing the reliability and validity of the constructs through confirmatory factor analysis, this research also used structural equation modelling (SEM) approach to test the proposed hypothesis.

Findings: The results from the inferential statistics revealed that the healthcare insurance customers are highly influenced by service quality followed by the perceived value in reaching their loyalty towards a particular health insurance service provider.

Research limitations/implications: The sample for this study is based on health insurance customers only and it is suggested that future studies enlarge the scope to include others type of customers of different insurance products. 
Practical implications: In order to encourage the customers to more loyal towards their service providers, this research will add value for the mangers to understand the items of service quality and considering the perceived value of the target customers in order to optimize their loyalty. As whole, the outcome of this research will assist managers for better understanding of the customers' loyalty antecedents under the perspective of healthcare insurance products.

Originality/value: This paper has tried to provide a comprehensive understanding about customers' loyalty under the perspective of service quality and perceived values context in the Malaysian health care insurance industry. Since there was a lack of such research in Malaysian health insurance context, this research can provide theoretical contribution and managerial basis for future researches as well as implications for the managers. Yet, till now research in this sector under Malaysian context do not appear adequately to take into account service quality, perceived values and customers loyalty factors.

Keywords: service quality, customer satisfaction, perceived value, customer loyalty, health insurance products, Malaysia

\section{Introduction}

In financial services, especially the insurance industry, the financial performance is intimately attached to customers loyalty (Diacon \& O'Brien, 2002). As the selling cost of an insurance policy is not recovered unless the policy is renewed (Zeithaml, Berry \& Parasuraman, 1996), thus, customer loyalty is one of the most important determinant of economic success to the insurance firms (Mishra \& Prasad, 2014; Moore \& Santomero, 1999). In this regard, customer loyalty is an area of interest not only in academia but among marketing practitioners (Lovelock, 2008; Sagib \& Zapan, 2014).

Although the relationship between customer satisfaction and customer loyalty has been researched in different industry at large, however the examination of the impact of the relationship between perceived value and loyalty has mostly been ignored by the health insurance perspective (Yang, Jun \& Peterson, 2004). For this reason, understanding the nature of service qualities towards the customers' perceived value of healthcare insurance products becomes more critical, and hence, customer loyaltyhas also become a top priority issue by numerous researchers (Bloemer \& Odekerken-Schroder, 2002; Chumpitaz \& Paparoidamis, 2004; Dobre, Dragomir \& Milovan-Ciuta, 2013; Iacobucci, Ostrom \& Grayson, 1995; Nelson, Rust, Zahorik, Rose, Batalden \& Siemanski, 1992; Zeithaml, 1988; Zeithaml \& Bitner, 1996). Commonly, the healthcare insurance service products are distributed through a very 
complicated insurance agency network (Grönroos, 1982). In this respect, building a distinctive and purposeful relationship between customers and the healthcare insurance providers will require a superior level of service qualities provided by insurance firms (Gera, 2011; Rahman, AbdelFattah \& Mohamad, 2014; Wong, Tong \& Wong, 2012).

Apart from service quality, Johnson and Weinstein (2004), state that a substantial competitive advantage can be gained by consistently providing superior perceived value to the respective customers'. Additionally, perceived value can be also created when the customer expectations match with product/service specifications (Arasli, Katircioglu \& Mehtap-Smadi, 2005; Dobre et al., 2013; Duodu \& Amankwah, 2011; Gyasi \& Azumah, 2009; Sasser, Schlesinger \& Heskett, 1997; Sharabi \& Davidow, 2010).

Despite the growing body of knowledge on service quality, there is hardly any research that combined service quality with customer perceived value towards customer loyalty in one integrated model under the scope of healthcare insurance products. Thus, there is a substantial gap exists in testing the service quality and customer loyalty in the healthcare insurance industry. Hence, the key interest of this research paper is to examine the service quality attributes as suggested by Gronroos (1984) towards customer loyalty as well as testing the mediated effect of customer's perceived value in the proposed relationship. In order to answer the following questions:

- How do the characteristics of service quality attributes (i.e. functional quality, technical quality and firm's image) influence the customer's perceived value in healthcare insurance service providers?

- Do customers perceive value play a mediating role between service quality attributes and customer loyalty?

\section{Development of Construct}

Empirical results indicated that service quality has a positive effect on customer's perceived value (Cronin, Brady \& Hult, 2000). Furthermore, Gronroos (2007) described technical quality as the quality of what the consumer actually receives as a result of interaction with the service firms and thereby is considered as important in assessing the quality of service in determining customer's satisfaction. On the other hand, functional quality is the method of how customers obtain the technical outcome in terms of viewing the service that has been received. Hence, functional quality has been initially conceptualised in the GAP model that was proposed by Parasuraman, Zeithaml and Berry (1985).

Aside from technical quality and functional quality, firm's image was drawn as an initial decision for customers to determine the quality of service provided (Clow, Kurtz \& Ozment, 
1998; Faché, 2000; Mazursky \& Jacoby, 1986). That's mean, when services are difficult to be evaluated, then firm image shown as an important factor that influencing the perception of customers towards the quality of service provided (Andreassen \& Lindestad, 1998; LeBlanc \& Nguyen, 2001). Previous studies established a positive relationship between the firm image and expectations in several service industries, such as catering, financial services, or travel agencies (Rodríguez del Bosque, San Martín, Collado \& García de los Salmones, 2009; Clow, Kurtz \& Ozment, 1997; Devlin, Gwynne \& Ennew, 2002). A positive firm image develops cues that give source of the appearance of expertise that are capable of increasing a message's of persuasive effect (Schindler \& Bickart, 2005).

As stated earlier, many studies have reported that there is a direct positive relationship between service quality and customer's loyalty (Bolton, 1998; Cronin \& Taylor, 1992; Oliver, 1980).

According to the aforementioned discussion, service quality attributes, may also be related to customer's loyalty, mediated by customer's perceived value. Previous empirical studies indicated that there was a positive relationship between service quality and customer loyalty (Avkiran, 1994; Bitner, Booms \& Tetreault, 1990; Johnston, 1997). In this regard, the current paper not merely adopted Gronroos (1984) model, but also expand the adopted model to include both customer perceived value and customer loyalty constructs in one integrated model for better understanding to the customers of healthcare insurance industry. Consequently, this paper attempt to examine three hypotheses that resulted from service quality attributes and customer loyalty through customer perceived value.

\subsection{Functional Quality and Technical Quality}

To be in the same line with other researchers like Dadfar, Brege and Semnani (2013), Sharabi and Davidow (2010) and Zeithaml and Bitner (2003), this paper employed functional quality measured through SERVQUAL items, in order to evaluate and assess the perception of customer's into specific dimensions, to include (reliability, responsiveness, assurance, empathy, and tangibility). In this research, we measured the service quality of health care insurance, by also investigating the technical quality terms through competence, reliability and responsiveness. Reliability is defined as the ability to perform a promised service consistency and precisely (Andaleeb \& Conway, 2006). Apart from that, responsiveness are known as willingness to help customers by providing them with quick and prompt service (Zeithaml, Bitner \& Gremler, 2006). In this regard, Gefen, Straub and Boudreau (2000) and Sandhu and Bala (2011) point out that both reliability and responsiveness ultimately, influence the customers' perceived service quality. Layton (1994) identifies knowledge; technical competence and technical will are the items to assess the technical quality. Rychen and Salganik (2003) described that competence is something that mobilize technology recourses. 
Thus, to meet the existing prerequisites of Malaysian healthcare insurance customers', providers may require being complemented in responding the changes that occur in today's technology advancement (Jonason \& Eliasson, 2001).

\subsection{Firms Image}

Corporate Image described as a company's image as how "customers see and perceive" the firm (Gronroos, 2007). Clow and Beisel (1995) and Mazursky and Jacoby (1986) added that the customer's image of particular service firm will have a direct effect on their attitude on future expectations. There is evidence that "image" is significantly related to perceptions of quality (Darden \& Schwinghammer, 1985). Because, the firm image will precede customer evaluations as these assessments are components of the image (Mazursky \& Jacoby, 1986).

\subsection{Perceived Value}

The concept of value was investigated by Zeithaml (1988). The researcher intends to identify two popular definitions of value by supporting literature. These are:

- The value is the quality I get for the price I pay, and

- value is what I get for what I give.

These two definitions have merged together and defined perceived value as the consumers' overall assessment based on the dimensions of utility theory. On the assumption that perceived product value and perceived service value are analogous, Bolton and Drew (1991) also carry the definition by Zeithaml (1988) to the service-oriented products. Rust and Oliver (1993) argue that it is likely that the value, like quality, is an encounter particular input to satisfaction. As stated earlier, many researchers have been studying service quality associated with customer satisfaction in life-insurance sector; however, what has not been tested is how the perceived value used as a mediating in between service quality and loyalty under the scope of the health insurance sector.

\subsection{Customer's Loyalty}

In this paper, we define customer loyalty as a composite construct by combining behavioural and attitudinal factors into one composite construct. Palmatier, Dant, Grewal and Evans (2006) view customer loyalty as a combined reflection of intentions, attitudes, and seller performance indicators. The loyalty concept in service provision in formulating marketing strategies is not a 
new phenomena (Wong et al., 2012). Apart from that, the role of managers in the service industry is to formulate strategies to raise the level of their customer loyalty that apparently lead service firm growth and foster business sustainability (Chen \& Cheng, 2012; Keiningham \& Aksoy, 2012).

Researchers also argued that customer loyalty increase firm's revenue and reduces the costs of customer acquisition and retention (Auka, 2012; Rapp, Beitelspacher, Schillewaert \& Baker, 2012; Reichheld, 1993; Reichheld \& Sasser, 1990). Thus, Krumay and Brandtweiner (2010), Mokhtar and Maiyaki (2011) and Wong et al. (2012) defined customer loyalty as the degree to which a customer exhibits repeat purchasing behaviour from a service provider, possesses a positive attitudinal disposition toward the provider, and considers using only this provider when a need for this service arises. The level of customer loyalty is measured by how willing a respondent is to recommend and say a good word-of-mouth about their respective healthcare insurance firms to their friends, relatives (Alok \& Srivastava, 2013; Arasli et al., 2005; Elmayar, 2011; LeBlanc \& Nguyen, 2001).

\section{Conceptual Framework}

Based on the above literature review; this research adopted the Gronroos service quality model for evaluating the service quality attributes (i.e. Functional quality, technical quality and firm's image) along with the customer's perceived value and customer loyalty. This research also investigates the role of customer's perceived value as a mediating construct in between the service quality attributes and customer loyalty. Figure 1 explains the proposed theoretical framework and proposed hypotheses to test in further in order to conclude the research.

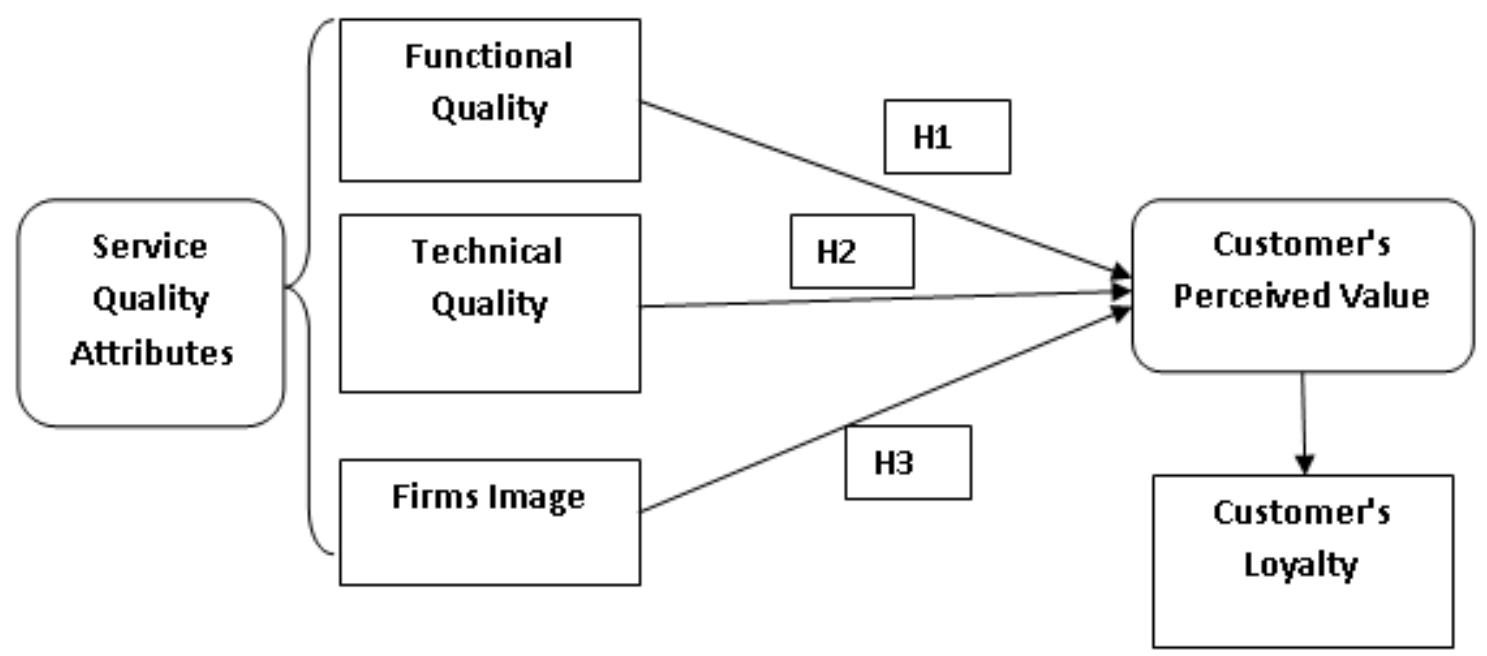

Figure 1. Theoretical Framework for the antecedents of Customer loyalty on Healthcare Insurance Products in Malaysia 


\subsection{Proposed Hypotheses}

H1. Customer loyalty is significantly determined by functional quality, in where customers perceived value played a mediating role.

H2. Technical quality significantly determines Customer loyalty, in where customer's perceived value played a mediating role.

H3. Customer loyalty is significantly determined by firm's image, in where customers perceived value played a mediating role.

\section{Research Methodology}

\subsection{Data Collection and Sampling}

Since the purpose of this research is to investigate the influence of service quality attributes towards customers' loyalty on health insurance products, a structured questionnaire was developed to collect the needed information from the healthcare insurance customers from Klang Valley area in Malaysia. Questionnaires were self-administered and distributed by utilizing a convenient sampling method. We used a convenience sampling method to select the participants for the reason that it is considered an effortless approach to get respondents to participate in a study of this nature. Besides, prior related researchers have used the similar method in selecting participants. This sampling method is frequently used in marketing research. It is also cost effective as we can choose anyone to be a participant with ease. The sampling frame for conducting the principal component analysis (PCA) comprised with 342 healthcare insurance customers.

Initially, the measurement items of the studied variables were drawn from existing theories and instruments adapted based on the previous studies. The adapted items were pre-tested with 35 healthcare insurance customers. From the results of the interview, a number of questions were modified to suit the context of this study. Cronbach alpha was used to examine the reliability test that is show that all items were above the cut-off value 0.70 (Nunnally \& Bernstein, 1994). Out of 450 distributed surveys, only 355 surveys were completed and returned. After, conducting the primarily screening test we confirmed that 342 surveys are valid for further analysis.

\subsection{Construct Measures}

The questionnaire has two parts. Part one includes the respondents' demographic information, e.g.: sex, age, job, educational level, marital status, race and the length of the period 
subscribing healthcare insurance. While Section two includes the indicators of the main elements of this study (service quality attributes, perceived value and customer loyalty). The items were developed from SERVQUAL elements to measure the functional quality variables. Functional quality was measured through 16 items (reliability-four items, assurance -four items, tangibility-four items, and empathy-four items). Adapted from Kang and James, (2004), and Parasuraman, Zeithaml and Berry (1988). This scale also proved to be adequately reliable $(a=0.92)$. Technical quality was operationalized by using four items adapted from Duodu and Amankwah (2011) ( $a=0.87)$. Firm's image was measured by four items adapted from Gurses and Kilic (2013). This scale also proved to be adequately reliable $(a=0.76)$. Perceived value was measured by four items adapted from (Sweeney \& Soutar, 2001). This scale also proved to be adequately reliable with Cronbach $a=0.82$. At last, the customer loyalty was measured by four items adapted from Aliza (2012) with $a=0.91$. All items were measured via 7-point Likert scale with rating scales categories ranging from $1=$ strongly disagree to $1=$ strongly agree.

\subsection{Data Analysis Method}

In this paper, the procedures to analysis the data on hand were systematized into two main steps. The first step was carried on confirmatory factor analysis (CFA). In this regard, researchers like Pett, Lackey and Sullivan (2003) and Thompson (2004) assured that using CFA provide the analysis with wide range of benefits to conclude; verifying the factor structure, confirm the convergent and divergent validity of the construct as well as CFA can support researcher to analyse and define the proposed model from a relatively significant of latent constructs to be presented by a set of points (Hair, Black, Babin \& Anderson, 2010; Nunnally, 1978). In addition, examining the general fit of the proposed model can help researchers to test and answer the research questions. Consequently, factor constructs were also employed based on the maximum likelihood (Fish, 2005). To be sure of the model goodness of fit, several criteria as suggested by (Jöreskog \& Sörbom, 1986), was also used to include, Chi-Square test, root mean square error of approximation (RMSEA), goodness-of-it index (GFI), adjusted goodness-of-fit index (AGFI), normed fit index (NFI), and comparative fit index (CFI).

On the other hand, the second step was conducting the Structural Equation Modeling (SEM) in order to test the previously mentioned hypotheses (Costello \& Osborne, 2005).

\subsection{Empirical Findings}

After the data collection, Table 1 shows that 342 usable questionnaires were used for further analysis, it also showed that (192) respondents were Malay. Followed by (100) respondents 
were Chinese, and only 50 were Indian. In regard to respondent gender, $55.7 \%$ was female, and $44.3 \%$ were male. Based on the respondents' profile, it was found that most of the respondents were within 31 to 35 years of age categories (57.6\%) followed by 26-30 years $(37.7 \%), 51$ and over (4.7\%). Apart from that, $(78.5) \%$ respondents have their insurance policy for more than five years. This analysis also found that most of the respondents $(82.3 \%)$ have both life and health insurance scheme under various private, local and international companies. In contrast, more than half of the respondents worked for different local and international companies; followed by $18 \%$ are students and $27 \%$ of various government departments. The bulk of the respondents were at least a bachelor degree holder (63\%) complied by a diploma (26\%) and (11\%) for higher education. The respondents were married (85\%) followed by single (15\%).

\begin{tabular}{|c|c|c|}
\hline & $\mathbf{n}$ & $\%$ \\
\hline \multicolumn{3}{|l|}{ Race } \\
\hline Malay & 192 & 56.14 \\
\hline Chinese & 100 & 29.23 \\
\hline \multirow[t]{2}{*}{ Indian } & 50 & 14.63 \\
\hline & 342 & $100 \%$ \\
\hline \multicolumn{3}{|l|}{ Gender } \\
\hline Male & 152 & $44.3 \%$ \\
\hline \multirow[t]{2}{*}{ Female } & 190 & $55.7 \%$ \\
\hline & 342 & $100 \%$ \\
\hline \multicolumn{3}{|l|}{ Age } \\
\hline $26-30$ & 129 & $37.7 \%$ \\
\hline 31 to 35 & 197 & $57.6 \%$ \\
\hline \multirow{2}{*}{51 and over } & 16 & $4.7 \%$ \\
\hline & 342 & $100 \%$ \\
\hline \multicolumn{3}{|c|}{ Length Of The Period Subscribing Healthcare Insurance } \\
\hline$>5$ years & 74 & 21.5 \\
\hline \multirow[t]{2}{*}{$<5$ years or above } & 268 & 78.5 \\
\hline & 342 & $100 \%$ \\
\hline \multicolumn{3}{|l|}{ Healthcare Insurance Type } \\
\hline Have healthcare insurance policy & 61 & 17.7 \\
\hline \multirow[t]{2}{*}{ Have both life and healthcare insurance } & 281 & $82.3 \%$ \\
\hline & 342 & $100 \%$ \\
\hline \multicolumn{3}{|l|}{ Employment } \\
\hline Government servant & 92 & 27 \\
\hline Private companies & 188 & 55 \\
\hline \multirow[t]{2}{*}{ Student } & 62 & 18 \\
\hline & 342 & $100 \%$ \\
\hline \multicolumn{3}{|l|}{ Background } \\
\hline Diploma & 89 & 26 \\
\hline Bachelor degree & 215 & 63 \\
\hline \multirow[t]{2}{*}{ Higher Education } & 38 & 11 \\
\hline & 342 & $100 \%$ \\
\hline \multicolumn{3}{|l|}{ Marital Status } \\
\hline Single & 51 & $15 \%$ \\
\hline \multirow{2}{*}{ Married } & 291 & $85 \%$ \\
\hline & 342 & $100 \%$ \\
\hline
\end{tabular}

Table 1. Descriptive statistics of demographic variables

\subsection{Analyzing the measurement model through (CFA)}

We used CFA in order to investigate the generalizability of multidimensional measures of the constructs. This research obtained unidimensionality through recognize the items of each 
factor loading for individual latent construct. This paper retained the items under each construct that have a loading higher than 0.6. According to the analytical output, there is no item loaded below 0.60. As a result, all items of each construct were remained.

As mentioned earlier, by using three fitness-indexed to examine the fitness of the proposed model, the fitness categorized were absolute fit, incremental fit and parsimonious fit Table 2, highlight the indexed and the level of acceptance, were utilized in both default and revised model.

\begin{tabular}{|c|c|c|c|c|}
\hline Name of Category & Index Name & Acceptance Level & Remarks & Source \\
\hline \multirow{3}{*}{ Absolute Fit } & Chi- Square & $p>0.05$ & $\begin{array}{l}\text { Sensitive to sample } \\
\text { size }>200\end{array}$ & $\begin{array}{l}\text { Bollen (1989); } \\
\text { Wheaton, Muthen, } \\
\text { Alwin and Summer } \\
\text { (1977) }\end{array}$ \\
\hline & RMSEA & RMSEA $<0.08$ & $\begin{array}{l}\text { Range } 0.05 \text { to } 1.00 \\
\text { acceptable }\end{array}$ & $\begin{array}{l}\text { Browne and Cudeck } \\
\text { (1993) }\end{array}$ \\
\hline & GFI & GFI $>0.90$ & $\begin{array}{l}\text { GFI }=0.95 \text { is a } \\
\text { good fit }\end{array}$ & $\begin{array}{l}\text { Jöreskog and Sörbom } \\
\text { (1986) }\end{array}$ \\
\hline \multirow{2}{*}{ Incremental Fit } & AGFI & AGFI $>0.90$ & $\begin{array}{l}\text { AGFI }=0.95 \text { is a } \\
\text { good fit }\end{array}$ & $\begin{array}{l}\text { Tanaka and Huba } \\
\text { (1984) }\end{array}$ \\
\hline & CFI & CFI $>0.90$ & $\begin{array}{l}\text { CFI }=0.95 \text { is a } \\
\text { good fit }\end{array}$ & $\begin{array}{l}\text { Bentler and } \mathrm{Hu} \\
(1999)\end{array}$ \\
\hline Parsimonious Fit & Chisq/df & Chi square/df $<5.0$ & $\begin{array}{l}\text { The value should } \\
\text { be less than } 5.0\end{array}$ & $\begin{array}{l}\text { Marsh and Hocevar } \\
\text { (1985) }\end{array}$ \\
\hline
\end{tabular}

Table 2. Level of acceptance to test the fitness of the individual constructs

\begin{tabular}{|c|c|c|c|c|c|c|c|}
\hline Theoretical Const & Model & $x^{2}$ & d.f. & $X^{2} /$ d.f. & GFI & RMSEA & CFI \\
\hline \multirow{2}{*}{ Functional Quality (FQ) } & Default (10 Items) & 256.09 & 35 & 7.316 & 0.867 & 0.127 & 0.646 \\
\hline & Revised & & 14 & 07 & 0.970 & 49 & 950 \\
\hline \multirow{2}{*}{ Technical Qualities (TQ) } & Defa & & 2 & 58 & 69 & 43 & 937 \\
\hline & Revis & 3. & 1 & 3.258 & 86 & 74 & 93 \\
\hline \multirow{2}{*}{$\begin{array}{l}\text { Firms Image (FI) } \\
\text { Customers' perceived } \\
\text { value (CPV) }\end{array}$} & Defa & 5.392 & 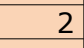 & 2.696 & .983 & 064 & 982 \\
\hline & Default (4 items) & 9 & 5 & 0 & 8 & 73 & 1 \\
\hline \multirow{2}{*}{ Customers' Loyalty (CL) } & Default ( $\epsilon$ & & 9 & 4.362 & 0.977 & & 0.952 \\
\hline & Revised (5 items) & 17.959 & 5 & 3.592 & 0.973 & 0.080 & 0.975 \\
\hline
\end{tabular}

Table 3. Level of acceptance of the unidimensional construct

From the results of the default model for functional quality, the modification indices for the covariance of measurement errors were 37.75 between Rel1 and Rel2, 33.34 between Ass 1 and Ass2, and 55.321 between Emp2 and Emp3. These three sets of measurement error were logically conceivable to be correlated. Based on observations, we deleted items Rel2, Ass2 and Emp2, which had almost the similar meaning. After deleting (Rel2, Ass2 and Emp2) items and testing, the revised measurement model was found fit for further analysis (see Table 2).

For technical quality, the modification indices for the covariance between the measurement errors of Tq1 and Tq2 were found to be 14.23. The correlation of these errors was logically possible, and, for this reason, the model was revised to incorporate this path (Table 2). After 
adding (Tq1 and Tq2) parameters, the measurement model fit indices of technical quality were found to fit adequately for further analysis. Among them, there were four measuring items for both constructs firm's image and consumers' perceived value. The fit indices for the default measurement model were found to fit adequately for these two constructs (see Table 2).

In addition, customers' loyalty modification indices showed that the covariance between CL3 and CL4 was 18.62. It is rationally conceivable that this pair of measurement errors is correlated as this research deleted one of the items (CL4); for this reason, the measurement model was revised. As a result, the amendment shows that all indices express an adequate fit of the model.

In addition to mentioned earlier, CFA was also used to verify the theoretical patterns of factor loadings on pre-specified constructs that represented the actual data. The model fit of the unidimensional construct, indicated by GFI, AGFI, RMSEA, CFI, NFI, TLI, resemble normal (see Table 2), which confirmed construct validity. The value of $x 2$ was significant for unidimensional constructs with a sample size $(\mathrm{N}=342)$. However, the normed $\times 2$ was within the suggested guidelines (see Table 2).

\begin{tabular}{|c|c|c|c|c|c|}
\hline Constructs & Item & $\begin{array}{l}\text { Factor } \\
\text { Loading }\end{array}$ & $\begin{array}{l}\text { Cronbach } \\
\text { Alpha }\end{array}$ & CR & AVE \\
\hline $\begin{array}{l}\text { Functional } \\
\text { Quality (FQ) }\end{array}$ & $\begin{array}{c}\text { Rel1 } \\
\text { Ass1 } \\
\text { Tan3 } \\
\text { Tan4 } \\
\text { Emp3 } \\
\text { Res3 } \\
\text { Res4 } \\
\end{array}$ & \begin{tabular}{r|}
0.75 \\
0.84 \\
0.89 \\
0.62 \\
0.76 \\
0.81 \\
0.72 \\
\end{tabular} & 0.74 & 0.934 & 0.670 \\
\hline $\begin{array}{l}\text { Technical } \\
\text { Qualities } \\
\text { (TQ) }\end{array}$ & $\begin{array}{c}\text { TQ1 } \\
\text { T2 } \\
\text { TQ3 } \\
\text { TQ3 } \\
\end{array}$ & \begin{tabular}{l|}
0.95 \\
0.93 \\
0.82 \\
0.77
\end{tabular} & 0.763 & 0.926 & 0.758 \\
\hline $\begin{array}{l}\text { Firms Image } \\
\text { (FI) }\end{array}$ & $\begin{array}{l}\text { FI1 } \\
\text { FI } 2 \\
\text { FI } 3 \\
\text { FI } 4 \\
\end{array}$ & \begin{tabular}{l|}
0.88 \\
0.86 \\
0.88 \\
0.76 \\
\end{tabular} & 0.763 & 0.910 & 0.717 \\
\hline $\begin{array}{l}\text { Customer } \\
\text { Perceived } \\
\text { Value (CPV) }\end{array}$ & $\begin{array}{l}\text { CPV1 } \\
\text { CPV2 } \\
\text { CPV3 } \\
\text { CPV4 } \\
\text { CPV5 }\end{array}$ & \begin{tabular}{l|}
0.81 \\
0.74 \\
0.74 \\
0.85 \\
0.87 \\
\end{tabular} & 0.751 & 0.901 & 0.646 \\
\hline $\begin{array}{l}\text { Customer } \\
\text { Loyalty (CL) }\end{array}$ & $\begin{array}{l}\text { CL1 } \\
\text { CL2 } \\
\text { CL3 } \\
\text { CL4 }\end{array}$ & \begin{tabular}{l|}
0.98 \\
0.92 \\
0.95 \\
0.96
\end{tabular} & 0.801 & 0.97 & 0.88 \\
\hline
\end{tabular}

Table 4. Distribution of Factor Loadings and CR, AVE

\subsection{Testing Hypothesis}

In analyzing the results of the structural model, this study utilized standardized estimates for all hypothesized paths. This research found that the functional quality (FQ), technical 
quality(TQ), and Firms image (FI) have a significant positive influence on customers' perceived value (CPV) (where, for FQ: $\beta=0.64$; S.E= .10; C.R = 6.23, $p<0.01$; for TQ: $\beta=0.23$; S.E . 066; $C . R=3.49, p<0.01$; for FI: $\beta=0.39 ; S . E=.087 ; C . R=4.52, p<0.01$ ). Additionally, we found that customers' perceived value was positively related to customers' loyalty (CL) $\beta=0.94 ;$ S.E $=.107 ; C . R=8.796, p<0.01$.

To determine the mediating role of customers' perceived value of functional quality, technical quality and firms image on customers' loyalty this research used a recommended method of testing the indirect effect through the bootstrapping technique (Bollen and Stine, 1990; Shrout and Bolger, 2002; Fritz et al. 2012; Kline, 2010; Baron and Kenny, 1986; Preacher and Hayes, 2010). The full model was tested based on the measurement model previously validated through CFA in the study. The fit indices of the full model were $X^{2} / d f=3.536\left(X^{2}=954.767 /\right.$ $270, \mathrm{df}=270) ; \mathrm{GFI}=0.842 ; \mathrm{AGFI}=.809 ; \mathrm{RMSEA}=0.080 ; \mathrm{CFI}=0.747$, which indicated a good fit. This research also concluded that all the proposed relationships in the hypotheses received favourable support. In addition, this study compared the magnitude of direct and indirect effect among functional and technical quality along with firms image on customers' loyalty. The total effect of technical quality was 0.64 with an indirect effect of 0.50 and direct impact of 0.14 . For this reason, we concluded that the indirect effect of perceived value was more dominant than the direct effect between technical quality and customers' loyalty. Hence, the customer loyalty is significantly influenced by the overall technical quality of a particular operator where perceived value plays a strong mediating role.

Likewise the total effect of functional quality by was 0.75 with an indirect effect of 0.50 and direct impact of 0.25 . We, for this reason, conclude that the indirect effect of perceived value was more dominant than the direct effect. Thus, customers' loyalty gain is significantly explained by the customers' perceived level of functional quality where customers' perceived value plays a strong mediating role. Finally, the total effect of firms was found to be 0.76 with an indirect effect of 0.30 and direct impact of 0.40 . Consequently, we concluded that the direct effect of perceived value was more dominant than the indirect effect. Hence, customer loyalty is significantly influenced by the firm's image where customers' perceived value plays a partial mediating role. Thus, we can conclude that a strong mediating effect flows from $\mathrm{FQ} \rightarrow \mathrm{CPV} \rightarrow \mathrm{CL}$; and $\mathrm{TQ} \rightarrow \mathrm{CPV} \rightarrow \mathrm{CL}$ compared to $\mathrm{FI} \rightarrow \mathrm{CPV} \rightarrow \mathrm{CL}$.

The estimated results show that the reliability and validity were reliable in assessing the unique nature of the variance on each construct (TQ, FQ, FI, and CPV). In addition, the findings indicate that the majority of the customers' is aware of the existing services and the providers based on the technical, functional and their firm's image where the perceived value play an important role to reach the loyalty towards a healthcare insurance. Subsequently, this research also suggests that Malaysian healthcare insurance products need to concentrate more on uplifting their technical and functional qualities to gain more customers as well as retain the existing one. 


\section{Conclusion and Managerial Implication}

This paper has provided empirical evidence which help practitioners of health care insurance products in Malaysia to be more focusing on the way of customers perceived the service quality as well as perceived values which in turns help on acquiring and maintaining customers. The results also showed that the measurement model was fit appropriately to investigate and comprehend customers loyalty toward the healthcare insurance industry in Malaysia.

In addition, customer's particularly in Malaysia are greatly concerned about the service quality and perceived value to reach loyalty towards healthcare insurance service providers which this finding consistent with Dick and Basu (1994) and Cronin et al., (2000). This finding is also consistent with the result found by Heskett, Jones, Loveman, Sasser and Schlesinger (1994) that loyalty is a direct result of customer perceived value and the quality of services obtained by their respective customers. On the other hand, the rivalry of the insurance industry in Malaysia is more intensified now than ever before. They need compete not only for the service quality that they are provided with maximizing to the medical network, but they also concern for acquiring a new customers and retention of old customers by direct and indirect price reduction. This finding is consistent with Zeithaml (1988), who asserted that in which goods and services can comprise any number of attributes; consumers typically infer quality from one or a few numbers of these attributes. In addition, Schlesinger and von der Schulenburg (1993), suggest that service quality is a factor upon which the customer can distinguish between identical insurance products. There are other characteristics of insurance that also influence the customer's choice. Such as, Leste and Wanderley (1997), reported in their study of the insurance industry that there are group of consumers, which takes the dimensions of a segment, who are particularly interested in the help and care that they receive from insurers and in the insurers' technical ability to provide information for the insurance products. In this regard, the health care insurance service providers should make such arrangements that would give extra value to the customers, in order to attain the customer loyalty. The service quality of the health insurance product is one the most important factor in increasing the overall customer loyalty. As a result, the healthcare insurance providers should be focused on the service quality attributes in order to sustain the loyalty of their quality seeking customers. The results of this study also suggest that the service provider should remain alert to take appropriate measures to enhance their service to strength the customer perceived value. In addition, this study suggests that reduced perceived value leads to decrease of customer loyalty. For this reason, the healthcare insurance providers in Malaysia should give prime focus on these elements to gain more long-term loyalty of their clients.

Although the perceived service quality has often been mentioned in consumer behavioural research, the intensity of the term "perceived service quality" has not been sufficiently examined in health insurance research. Thus, some important factors that affect perceived service quality have not been recognized or examined even in Malaysian health insurance 
sector. This research utilizes both technical quality and functional quality along with firm's image as suggested by Gronroos (1984) toward customer perceived value on customer's loyalty. As a result, the outcome of this research has highlighted the cues that lead to the assessments of each construct of the study. Therefore, this research successfully explains the contribution of the exogenous constructs in clarifying the customer loyalty from the perspective of health insurance consumers.

\section{Study Limitation and Direction for Further Study}

This research additionally contains some limitations that suggest a possibility for additional further research. The data originated from a convenience sample procedure. Further studies may include a more representative sampling structure. The constructs could be further explored and compared across services of different types of industry. This paper could not include Sabah and Sarawak states where a notable population of health care insurance customers also exists. The demographic characteristics, such as age, gender and race are often assumed to have a significant effect on customer intention to have healthcare insurance products. While this research used a wide variety of measures to minimize any possible halo effects, it would also be useful for future research to assess some of these variables more directly, such as a cross-country comparison to measure the relationship of overall satisfaction and behavioural intention on the consumers' perceptions of the service quality of a particular provider in the healthcare insurance context. In addition, this research assured that further investigations on this particular issue (healthcare insurance products) are required to investigate more with larger samples before generalization can be made.

\section{References}

Aliza, N. (2012). The Importance of Healthcare Insurance Policy on Purchase Intention/ Continuance- An Empirical Study in Malaysia. Ph.D thesis, Universiti Sains Malaysia (USM).

Alok, K.R., \& Srivastava, M. (2013). The Antecedents of Customer Loyalty: An Empirical Investigation in Life Insurance Context. Journal of Competitiveness, 5(2), 139-163. http://dx.doi.org/10.7441/joc.2013.02.10

Andaleeb, S.S., \& Conway, C. (2006). Customer satisfaction in the restaurant industry: An examination of the transaction-specific model. Journal of Services Marketing, 20(1), 3-11. http://dx.doi.org/10.1108/08876040610646536 
Andreassen, T.W., \& Lindestad, B. (1998). Customer loyalty and complex services: The impact of corporate image on quality, customer satisfaction and loyalty for customers with varying degrees of service expertise. International Journal of Service Industry Management, 9(1), 7-23. http://dx.doi.org/10.1108/09564239810199923

Arasli, H., Katircioglu, S.T., \& Mehtap-Smadi, S. (2005). A comparison of service quality in the banking industry: Some evidence from Turkish and Greek-speaking areas in Cyprus. International Journal of Bank Marketing, 23(7), 508-526. http://dx.doi.org/10.1108/02652320510629881

Auka, D. (2012). Service quality, satisfaction, perceived value and loyalty among customers in commercial banking in Nakuru Municipality, Kenya. African Journal of Marketing Management, 4(5), 185-203. http://dx.doi.org/10.5897/AJMM12.033

Avkiran, N. (1994). Developing an instrument to measure customer service quality in branch banking. International Journal of Bank Marketing, 12(6), 10-18. http://dx.doi.org/10.1108/02652329410063223

Bentler, P.M., \& Hu, L. (1999). Cutoff criteria for fit indexes in covariance structure analysis: Conventional criteria versus new alternatives. Structural Equation Modeling: $A$ Multidisciplinary Journal, 6(1), 1-55. http://dx.doi.org/10.1080/10705519909540118

Bitner, M., Booms, B., \& Tetreault, M. (1990). The service encounter: Diagnosing favorable and unfavorable incidents. The Journal of Marketing, 54(1), 71-84. http://dx.doi.org/10.2307/1252174

Bloemer, J., \& Odekerken-Schroder, G. (2002). Store satisfaction and store loyalty explained by customer-and store-related factors. Journal of Consumer Satisfaction Dissatisfaction and Complaining Behavior, 15(1), 68-80.

Bollen, K.A. (1989). Structural Equations with Latent Variables. New York: Wiley. http://dx.doi.org/10.1002/9781118619179

Bollen, K.A., \& Stine, R. (1990). Direct and indirect effects: Classical and bootstrap estimates of variability. Sociological Methodology, 20(1), 115-140. http://dx.doi.org/10.2307/271084

Bolton, R.N. (1998). A Dynamic Model of the Duration of the Customer's Relationship with a Continuous Service Provider: The Role of Satisfaction. Marketing Science, 17(1), 45-65. http://dx.doi.org/10.1287/mksc.17.1.45

Bolton, R.N, \& James H.D. (1991). A Multi-Stage Model of Customers' Assessments of Service Quality and Value. Journal of Consumer Research, 17(4), 375-384. http://dx.doi.org/10.1086/208564 
Browne, M.W., \& Cudeck, R. (1993). Alternative Ways of Assessing Model Fit. In K. A. B. And \& J. S. Long (Eds.), Testing Structural Equation Models. Newbury Park, CA: Sage Publications.

Chen, C.-F., \& Cheng, L.-T. (2012). A study on mobile phone service loyalty in Taiwan. Total Quality Management \& Business Excellence, 23(7-8), 807-819. http://dx.doi.org/10.1080/14783363.2012.661129

Chumpitaz, R., \& Paparoidamis, N.G. (2004). Service quality and marketing performance in business-to-business markets: Exploring the mediating role of client satisfaction. Managing Service Quality: An International Journal, 14(2/3), 235-248. http://dx.doi.org/10.1108/09604520410528653

Clow, K.E., \& Beisel, J.L. (1995). Managing consumer expectations of low-margin, high-volume services. Journal of Services Marketing, 9(1), 33-46. http://dx.doi.org/10.1108/08876049510079871

Clow, K.E., Kurtz, D.L., Ozment, J., \& Ong, B.S. (1997). The antecedents of consumer expectations of services: An empirical study across four industries. Journal of Services Marketing, 11(4), 230-248. http://dx.doi.org/10.1108/08876049710171704

Clow, K., Kurtz, D., \& Ozment, J. (1998). A longitudinal study of the stability of consumer expectations of services. Journal of Business Research, 42(1), 63-73. http://dx.doi.org/10.1016/S0148-2963(97)00098-2

Costello, A.B., \& Osborne, J. (2005). Best practices in exploratory factor analysis: Four recommendations for getting the most from your analysis. Practical Assessment Research \& Evaluation, 10(7) 131-146. Available online at: http://pareonline.net/getvn.asp?v=10\&n=7

Cronin, J.J., Brady, M.K., \& Hult, G.T.M. (2000). Assessing the effects of quality, value, and customer satisfaction on consumer behavioral intentions in service environments. Journal of Retailing, 76(2), 193-218. http://dx.doi.org/10.1016/S0022-4359(00)00028-2

Cronin, J.J., \& Taylor., S.A. (1992). Measuring service quality: A re-examination and extension. The Journal of Marketing, 56(July), 55-68.

Dadfar, H., Brege, S., \& Semnani, S.S.E. (2013). Customer involvement in service production, delivery and quality: The challenges and opportunities. International Journal of Quality and Service Sciences, 5(1), 46-65. http://dx.doi.org/10.1108/17566691311316248

Darden, W.R., \& Schwinghammer, J.K. (1985). Effects of Price, Brand and Store Information on Buyers' Product Evaluations. In J. Jcob \& J. Olson (Eds), Perceived quality: How consumers view stores and merchandise (pp. 161-172). MA: Lexington Books Lexington.

Devlin, J.F., Gwynne, A.L., \& Ennew, C.T. (2002). The Antecedents of Service Expectations. The Service Industries Journal, 22(4), 117-152. http://dx.doi.org/10.1080/714005102 
Diacon, S., \& O'Brien, C. (2002). Persistency in UK long-term insurance: Customer satisfaction and service quality. CRIS Discussion Paper, III.

Dick, A., \& Basu, K., (1994). Customer loyalty: Towards an integrated framework. Journal of the Academy of Marketing Science, 22(2), 99-113. http://doi.org/10.1177/0092070394222001

Dobre, C., Dragomir, A.C., \& Milovan-Ciuta, A.-M. (2013). A marketing perspective on the influences of waiting time and the service scape on perceived value. Management \& Marketing, 8(4), 683-698.

Duodu, F.K., \& Amankwah, T. (2011). An Analysis and Assessment of Customer Satisfaction with Service Quality in Insurance Industry in Ghana. Lulea University Of Technology.

Elmayar, A. (2011). Assessing the Perceived Service Quality Levels in the Libyan Private and Public Banking Sectors: A Customer Perspective. The University of Northumbria at Newcastle Upon Tyne.

Faché, W. (2000). Methodologies for innovation and improvement of services in tourism. Managing Service Quality, 10(6), 356-366. http://dx.doi.org/10.1108/09604520010351185

Gefen, D., Straub, D., \& Boudreau, M.-C. (2000). Structural Equation Modeling and Regression: Guidelines for Research Practice. Communications of the Association for Information Systems, 4(7), 1-7.

Gera, R. (2011). Modelling the service antecedents of favourable and unfavourable behaviour intentions in life insurance services in India: An SEM study. International Journal of Quality and Service Sciences, 3(2), 225-242. http://dx.doi.org/10.1108/17566691111146113

Gronroos, C. (1984). A Service Quality Model and its Marketing Implications. European Journal of Marketing, 18(4), 36-44. http://dx.doi.org/10.1108/EUM0000000004784

Gronroos, C. (2007). In Search of a New Logic for Marketing: Foundations of Contemporary Theory (pp. 34-36). Chichester: John Wiley \& Sons.

Grönroos, C. (1982). Strategic Management and Marketing in the Service Sector (p. 222). Swedish School of Economics and Business Administration.

Gurses, S., \& Kilic, K.C. (2013). Corporate Image Aspect of Corporate Management in Healthcare Industry: Definition, Measurement and an Empirical Investigation. International Business Research, 6(12), 31-46. http://dx.doi.org/10.5539/ibr.v6n12p31

Gyasi, N., \& Azumah, F. (2009). An assessment and analysis of customer satisfaction with service delivery of mobile telecommunication networks in Ghana. Lulea University of Technology. 
Hair, J.F., Black, W.C., Babin, B.J., \& Anderson, R.E. (2010). Multivariate Data Analysis (7th ed.). New Jersey: Prentice Hall.

Heskett, J.L., \& Schlesinger, L.A. (1994). Putting the service: Profit chain to work. Harvard Business Review, 72(2), 164-174.

Iacobucci, D., Ostrom, A., \& Grayson, K. (1995). Distinguishing service quality and customer satisfaction: The voice of the consumer. Journal of Consumer Psychology, 4(3), 277-303. http://dx.doi.org/10.1207/s15327663jcp0403_04

Johnson, W.C., \& Weinstein, A. (2004). Superior Customer Value in the New Economy: Concepts and Cases. Boca Raton, FL: CRC Press. http://dx.doi.org/10.1201/9780203501498

Johnston, R. (1997). Identifying the critical determinants of service quality in retail banking: Importance and effect. International Journal of Bank Marketing, 15(4), 111-116. http://dx.doi.org/10.1108/02652329710189366

Jonason, A., \& Eliasson, G. (2001). Mobile Internet revenues: An empirical study of the I-mode portal. Internet Research, 11(4), 341-348. http://dx.doi.org/10.1108/10662240110402795

Jöreskog, K.G., \& Sörbom, D. (1986). LISREL VI, analysis of linear structural relationships by maximum likelihood, instrumental variables, and least squares methods. Scientific Software, Inc.

Kang, G.-D., \& James, J. (2004). Service quality dimensions: An examination of Grönroos's service quality model. Managing Service Quality, 14(4), 266-277. http://dx.doi.org/10.1108/09604520410546806

Keiningham, T., \& Aksoy, L. (2012). Linking customer loyalty to growth. MIT Sloan Management Review, 49(4), 51-57.

Krumay, B., \& Brandtweiner, R. (2010). Are Customer Service Offerings Influencing E-Loyalty? A Graphical Chain Model Approach in the Austrian Mobile Phone Service Provider Industry. In BLED 2010 Proceedings. Paper 17.

Layton, D. (1994). A school subject in the making? The search for fundamentals. In D. Layton (Ed.), Innovations in science and technology education. Paris: UNESCO.

LeBlanc, G., \& Nguyen, N. (2001). An exploratory study on the cues that signal value to members in retail co-operatives. International Journal of Retail \& Distribution Management, 29(1), 49-59. http://dx.doi.org/10.1108/09590550110366361

Leste, M.R., \& Wanderley, V. (1997). The Interactive Approach to service quality and management. Deuxième Congres International Franco Quebecois de Génie Industriel, ALBI. 
Lovelock, C. (2008). Services Marketing People, Technology, Strategy (6th ed.). New Jersey: Prentice-Hall Inc.

Marsh, H.W., \& Hocevar, D. (1985). Application of Confirmatory Factor Analysis to the Study of Self-concept: First- and Higher Order Factor Models and Their Invariance across Groups. Psychological Bulletin, 97(3), 562-582. http://dx.doi.org/10.1037/0033-2909.97.3.562

Mazursky, D., \& Jacoby, J. (1986). Exploring the development of store images. Journal of Retailing, 1(62), 145-165.

Mishra, S., \& Prasad, S. (2014). Exploring linkages between socio-demographic factors and customer loyalty in India. Management \& Marketing, 9(1), 13-26.

Mokhtar, S., \& Maiyaki, A. (2011). The Relationship Between Service Quality and Satisfaction on Customer Loyalty in Malaysian Mobile Communication Industry. European Union Journal, $2(3), 32-38$.

Moore, J., \& Santomero, A. (1999). The industry speaks: Results of the WFIC insurance survey. In A.. Cummins, J.D. and Santomero (Ed.), Changes in the Life Insurance Industry: Efficiency, Technology and Risk Management. Norwell, MA.: Kluwer.

Nelson, E.C., Rust, R.T., Zahorik, A., Rose, R.L., Batalden, P., \& Siemanski, B.A. (1992). Do patient perceptions of quality relate to hospital financial performance?. Journal of Health Care Marketing, 12(4), 6-13.

Nunnally, J.C. (1978). Psychometric Theory (2nd ed.). New York: McGraw-Hill.

Nunnally, J.C., \& Bernstein, I.H. (1994). Psychometric Theory (3rd Ed.). New York: McGrawHill.

Oliver, R.L. (1980). A Cognitive Model of the Antecedents and Consequences of Satisfaction Decisions. Journal of Marketing Research, 17(4), 460-469. http://dx.doi.org/10.2307/3150499

Palmatier, R.W., Dant, R.P., Grewal, D., \& Evans, K.R. (2006). Factors Influencing the Effectiveness of Relationship Marketing: A Meta-Analysis. Journal of Marketing, 70(4), 136-153. http://dx.doi.org/10.1509/jmkg.70.4.136

Parasuraman, A., Zeithaml, V., \& Berry, L. (1985). A conceptual model of service quality and its implications for future research. The Journal of Marketing, 49(2), 41-50. http://dx.doi.org/10.2307/1251430

Parasuraman, A., Zeithaml, V.A., \& Berry, L.L. (1988). SERVQUAL: A Multiple-Item Scale for Measuring Consumer Perceptions of Service Quality. Journal of Retailing, 64(1), 12-40. http://dx.doi.org/10.1016/S0148-2963(99)00084-3 
Pett, M.A., Lackey, N.R., \& Sullivant, J.J. (2003). Making Sense of Factor Analysis: The use of factor analysis for instrument development in health care research. California: SAGE Publications, Inc.

Rahman, M., AbdelFattah, F., \& Mohamad, O. (2014). Service Quality and Customers' Patronage Decision of Healthcare Insurance Products: In-Depth Interview Approach. Hrmars.com, 4(7), 526-544. http://dx.doi.org/10.6007/IJARBSS/v4-i7/1046

Rapp, A., Beitelspacher, L.S., Schillewaert, N., \& Baker, T.L. (2012). The differing effects of technology on inside vs. outside sales forces to facilitate enhanced customer orientation and interfunctional coordination. Journal of Business Research, 65(7), 929-936. http://dx.doi.org/10.1016/j.jbusres.2011.05.005

Reichheld, F.F. (1993). Loyalty-Based Management. Harvard Business Review, 71(2), 64-73.

Reichheld, F.F., \& Sasser, W. (1990). Zero defections: Quality comes to services. Harvard Business Review, 68(5), 105-111.

Rodríguez del Bosque, I., San Martín, H., Collado, J., \& García de los Salmones, M.M. (2009). A framework for tourist expectations. International Journal of Culture, Tourism and Hospitality Research, 3(2), 139-147. http://dx.doi.org/10.1108/17506180910962140

Rust, R.T., \& Oliver, R.L. (1993). Service Quality: New Directions in Theory and Practice (Vol. 15). Thousand Oaks, California: SAGE Publications.

Rychen, D.S., \& Salganik, L.H. (2003). Key competencies for a successful life and wellfunctioning society. Göttingen, Lower Saxony: Hogrefe Publishing.

Sagib, G.K., \& Zapan, B. (2014). Bangladeshi mobile banking service quality and customer satisfaction and loyalty. Management \& Marketing. Challenges for the Knowledge Society, 9(1), 331-346.

Sandhu, D., \& Bala, M. (2011). Customers' Perception towards Service Quality of Life Insurance Corporation of India: A Factor Analytic Approach. International Journal of Business and Social Science, 2(18), 219-231.

Sasser, W.E., Schlesinger, L.A., \& Heskett, J.L. (1997). Service Profit Chain (p. 320). New York: Simon and Schuster.

Schindler, R., \& Bickart, B. (2005). Published word of mouth: Referable, consumer-generated information on the Internet. In and R. Y. C.P. Haugtvedt, K.A. Machlei (Ed.), Online Consumer Psychology: Understanding and Influencing Consumer Behaviour in the Virtual World. New York: Lawrence Erlbaum Associates, Inc. 
Schlesinger, H., \& von der Schulenburg, J.-M.G. (1993). Consumer Information and Decisions to Switch Insurers. The Journal of Risk and Insurance, 60(4), 591-615. http://dx.doi.org/10.2307/253381

Sharabi, M., \& Davidow, M. (2010). Service quality implementation: Problems and solutions. International Journal of Quality and Service Sciences, 2(2), 189-205. http://dx.doi.org/10.1108/17566691011057357

Sweeney, J.C., \& Soutar, G.N. (2001). Consumer perceived value: The development of a multiple item scales. Journal of Retailing, 77(2), 203-220. http://dx.doi.org/10.1016/S00224359(01)00041-0

Tanaka, J.S., \& Huba, G.J. (1984). Confirmatory Hierarchical Factor Analyses of Psychometric Distress Measures. Journal of Personality and Social Psychology, 46(1), 621-635. http://dx.doi.org/10.1037/0022-3514.46.3.621

Thompson, B. (2004). Exploratory and confirmatory factor analysis: Understanding concepts and applications. Washington, DC: American Psychological Association. http://dx.doi.org/10.1037/10694-000

Wheaton, B., Muthen, B., Alwin, D.F., \& Summer, G.F. (1977). Assessing reliability and stability in panel models. In D. R. Heise (Ed.), Assessing reliability and stability in panel models. San Francisco: Jossy-Bass. http://dx.doi.org/10.2307/270754

Wong, R., Tong, C., \& Wong, A. (2012). Examine the Effects of Customer Satisfaction on Customer Loyalty: An Empirical Study in the Healthcare Insurance Industry in Hong Kong. British Journal of Economics, Management \& Trade, 4(3), 372-399. http://dx.doi.org/10.9734/BJEMT/2014/6318

Yang, Z., Jun, M., \& Peterson, R.T. (2004). Measuring customer perceived online service quality: Scale development and managerial implications. International Journal of Operations \& Production Management, 24(11), 1149-1174. http://dx.doi.org/10.1108/01443570410563278

Zeithaml, V.A. (1988). Consumer Perceptions of Price, Quality, and Value: A Means-End Model and Synthesis of Evidence. The Journal of Marketing, 52(3), 2-22. http://dx.doi.org/10.2307/1251446

Zeithaml, V.A., \& Bitner, M.J. (1996). Services Marketing. New York: McGraw-Hill.

Zeithaml, V.A., \& Bitner, M.J. (2003). Services Marketing: Integrating Customer Focus Across the Firm. New Jersey: McGraw-Hill.

Zeithaml, V.A., Berry, L.L., \& Parasuraman, A. (1996). The Behavioural Consequences of Service Quality. Journal of Marketing, 60(2), 31-46. http://dx.doi.org/10.2307/1251929 
Zeithaml, V.A., Bitner, M.J., \& Gremler, D.D. (2006). Services Marketing: Integrating customer focus across the firm. New York: McGraw-Hill.

Journal of Industrial Engineering and Management, 2015 (www.jiem.org)

Article's contents are provided on an Attribution-Non Commercial 3.0 Creative commons license. Readers are allowed to copy, distribute and communicate article's contents, provided the author's and Journal of Industrial Engineering and Management's names are included. It must not be used for commercial purposes. To see the complete license contents, please visit http://creativecommons.org/licenses/by-nc/3.0/. 